磁気リコネクンョンの物理

佐 藤 哲也

（広島大学・核融合理論研究センター），

( 1983 年 2 月 4 日受理)

\title{
Physics of Magnetic Reconnection
}

\author{
Tetsuya Sato
}

(Received February 4, 1983)

\begin{abstract}
\end{abstract}
Magnetic reconnection process is reviewed with particular emphasis on its physical impacts on plasma confinement and acceleration. In the first place, heuristically discussed are the existence and importance of some violent process in laboratory and space plasmas that breaks the frozen-in principle; this is the magnetic reconnection process. It cuts and connects the magnetic surface, accordingly, plasma particles separated by the surface are mixed up and those residing in the same domain are separated out. On occasions, plasmas are explosively accelerated. In the second place, the topological condition for magnetic reconnection is given and the strength of reconnection is defined. Then, two basic theoretical models leading to reconnection, Petschek model and tearing mode instability, are described as representatives of explosive acceleration and plasma mixing, respectively. Finally, some examples of numerical simulations on externally driven reconnection and tearing instability are presented.

§1. はじめに

プラズマの振舞の面白さには二つの側面がある。一つはプラズマの構成粒子と波の相互作用に 基づく華麗で繊細な振舞であり，もう一つはこの粒子的性質のみではひき起こすことのできない 大胆でドラマティックな変化をもたらす流体的振舞の魅力である。例えば，プラズマを磁力線と いう檻に閉じ込めようとすると，プラズマ粒子は波と協力して檻に無数の小さな穴を開け，そこ から必み出すように逃げ出そうとする。これに対し，時には，檻の鉄棚を切り倒し一度にどっと

Institute for Fusion Theory Hiroshima University Hiroshima 730, Japan 


\section{佐 藤}

集団脱走を計ることもある。このプラズマの大脱走という行動はプラズマの粒子的側面のみから は起こり得ない現象の一例である。

磁場のあるプラズマの流体的振舞を演じる主役は，横波としてのアルフベン波と縦波としての 磁気音波（ファーストモードとスローモード）に過ぎないが，彼等の演じる役割は時にはプラズ マ全体の運命を制する。とりわけ，磁気りコネクションと呼ばれる磁力線を局所的につなぎ変え る技と電磁流体波との合わせ技はプラズマの振舞に大いなる巾を持たせ，電磁流体プラズマを興 味ある対象にしてくれる。宇宙空間における样々な爆発的電磁現象，トカマクプラズマの崩壊現 象など自然発生的に生じる様々の現象の起爆薬としてのみならず，最近では，この磁気りコネク ションを積極的に利用してプラズマの閉じ込め磁場配位を生成・整形しょうとする考え方もでて きている。

この解説では，磁気りコネクション，特にプラズマ配位の大規模な変形，エネルギー変換を司 る電磁流体的インパクトとしての磁気りコネクション過程に主眼を置くことにする。

次節では，トーラス状プラズマの閉じ込めの大前提である凍結の原理から話を進め，それを劇 的に破る機構としての磁気りコネクションの存在，§3では，そのリコネクションの起きる条件， その物理的性質, 役割について論ずる。ミ4では, リコネクションの代表的な 2 つ理論モデル を紹介し，§5では，その非線形発展を解くジュレーション結果をいくつか紹介する。最後に， そのまとめを行う。

$\S 2$. 凍結の解除からリコネクションへ

プラズマは我々の古典電磁気学に対する造詣の深さを試してくれる最もよい対象であろう。電 磁気学の法則のほそんどが経験則に基づいているだけにプラズマの具体的問題，例えば，境界の あるプラズマ中の磁力線の運動，を考える場合，我々の（私のと言った方が正確）理解の浅さに 愕然とさせられることが多い。しかも，よくかみしめると意外に味わい深く，面白い性質が隠さ れていることに気がつく。

磁束の凍結という概念もそのような例である。磁束の変化と誘導起動力との関係を与えるファ ラデーの法則と起電力と磁場中の導体の運動の関係を示ずフレングの右手の法則をプラズマと いう導電性流体に適応して生まれたのが磁束とプラズマの運動の凍結という原理であり，この原 理が核融合プラズマの磁場閉じ込めの大前提でもある。磁場閉じ込め核融合プラズマ研究は，こ の原理を破ろうとするプラズマの電磁気作用とそれら防ごうとするプラズマ研究者との戦いとも 
磁気りコネクションの物理

いえる。

凍結を破るということは，プラズマの構成粒子のどちらか一方 (あるいは両方) が磁気面と異 なる運動, 即ち, 粒子と磁気面のスリッブを起こすことを意味する。従って, 凍結を破る, 言い 換えるとプラズマの閉じ込めを破る，ということは磁気面軌道からの粒子の逸脱，つまり，広い 意味での衝突の存在を意味する。例えば，無衝突ドリフト波による異常拡散も凍結の理を破った 結果であり，その原因は，電子のランダウ減衰による運動量の損失という電子と波の衝突と解釈 することができる。

磁場とプラズマが一体となって運動するという凍結の意味を別の面から表現すると，ある場所 で生まれた磁場とプラズマは，凍結が解除されない限り，未来永劫他のプラズマとは相交わらな いことを意味する。このことは，例えば，太陽起源のプラズマ（太陽風）は地球磁場の中には入 り込めないことを意味している。従って，地球磁気圈内のプラズマは太陽光によって電離された 地球大気のプラズマのみでなければならないことになる。しかし実際の磁気圈プラズマの構成粒 子には太陽起源の粒子が多数含まれている。このことは磁気圈と太陽風の境界面（磁気面）にお いて凍結を破る何んらかの作用が働いていることを示唆している。観測事実は，トカマクにおけ るようにほぼ定常的にじわじわと凍結が破られているという部分とスポラディックにしかも急激 に破られる部分があることを暗示している。後者は，磁気圈サブストームと呼ばれる嵐を磁気圈 全域にひき起こし，地上にはオ一ロラという光の絵巻を展開する。

有理面で仕切られたトカマクプラズマにも，先に述べた異常拡散とは別に，急激にドラマティ ックに磁気面の破壊が進行することがあることを実験は示している。ディスラプション現象がそ れである。

このディスラプション現象やサブストーム現象の存在は, 粒子の磁気面からの拡散という繊細 な機構では説明できず，ょり大胆な凍結解除機構の存在を強く示唆している。

ここで，粒子の磁場を横切る拡散が粒子の磁場からの逸脱という側面から説明されるのに対し， 逆に磁場のプラズマからの逸脱という発想の転換をしてみよう。つまり，磁場の拡散である。磁 場の拡散は電気抵抗に依存して晾り, 電流の流れている領域, 即ち, 磁場のシアーのある領域で 生じる。そこでは, 磁場のエネルギーがオーム加熱によりプラズマの熱エネルギーに変換される。 従って，単なる磁場拡散過程はプラズマ加鷲を起こすだけでディスラプションやサブストームと いったプラズマの状態変化を伴うと法到底考えられない。しかしながら，ある特殊なプラズマ環 境においては磁場の拡散が引き金となり，相隔てた磁気面が局所的に破れ，お互いの磁力線がつ 
ながり，それを通してプラズマが混り合い，条件によっては急激なプラズマ加速を伴うことがあ る。この局所的な磁場の拡散に伴って磁場のトポロジーに変化をもたらす機構を磁気りコネクシ ョンと呼ぶ。次節ではこのリコネクション機構の性質と役割りについて説明する。

\section{$\S 3$. 発生条件, 物理的性質及び物理的役割}

まず，磁気りコネクションのトポロジーから話を進める。磁力線が完全に平行であれば，拡散 が生じることはあり得るが磁場のトポロジーが変化することはない。逆に, 完全に反平行な 2 本 の磁力線を考えるとトポロジカルには結びかえが可能である。従って，磁気りコネクションが生 じるトポロジカルな条件として少なくとも局所的に反平行磁場成分が必要であることが予想され る。そこで， 3 次元的に見て磁力線がつなぎ変わり得るトポロジカルな条件を求めてみよう。

任意角度を有する 2 本の磁力線が互いに接近してきた場合を想定する。［図 $1 \mathrm{a}$ ］はその接点 （ $\mathrm{x}$ 点と呼ぶ）に扔ける接平面上に画いた 2 本の接点における磁力線べクトルを示す。これらの 磁力線がトポロジカルにつなぎ変わる条件は，2つのべクトルを互いに直交したベクトルに分解 したとき，一方が同じ大きさをもち，他方が互いに逆方向成分を有するときである。言い換える と，共通したベクトル成分を差し引い たとき，残る成分が互いに反平行成分 をもつときトポロジカルに見て磁力線 は[図1 b] のようにつなぎ変光が可 能となる。トカマクにおけるモード有 理面は正にこの条件を満たしている。

今, $\mathrm{x}$ 点での 2 らの磁力線べクトル
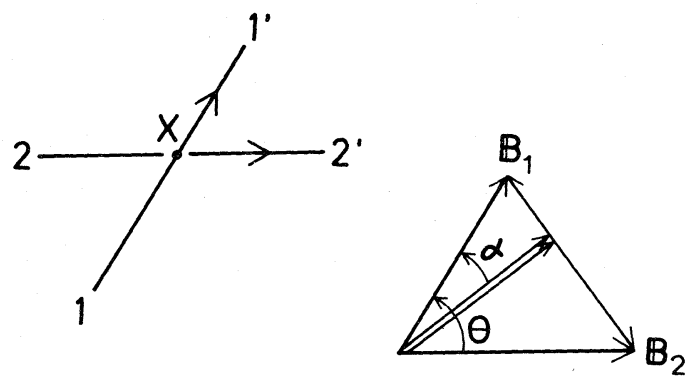

$\mathrm{B}_{1} ， \mathrm{~B}_{2}$ のなす角を $\theta(0<\theta<\pi)$ とするとき上の条件は次式で与えられ る。

$\cos \theta<\min \left(\frac{\mathrm{B}_{2}}{\mathrm{~B}_{1}}, \frac{\mathrm{B}_{1}}{\mathrm{~B}_{2}}\right)$ ここに $\mathrm{B}_{1}, \mathrm{~B}_{2}$ は $\mathrm{B}_{1}, \mathrm{~B}_{2}$ の絶対 值を示す。従って, 同じ大きさの 2 本 の磁力線治完全に平行でない限り常に

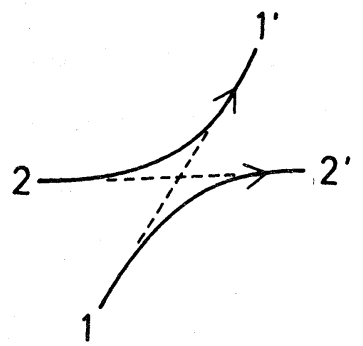

図 1.2本の磁力線の接点における磁力線ベクトルとつなき 変ったときの磁力線トポロジー。 
磁気りコネクションの物理

つなぎ変えが可能である。また，両べクトルのなす角が $90^{\circ}$ 以上であるときもつなぎ変光が可能 となる。逆に，つなぎ変えの発生しえない条件は， $\mathrm{B}_{2} \geq \mathrm{B}_{1}$ として，

$$
\theta \leq \theta_{\mathrm{c}}
$$

のときである。ここに $\theta_{\mathrm{c}}=\cos ^{-1}\left(\mathrm{~B}_{1} / \mathrm{B}_{2}\right)$ 。

磁力線のつなぎ変わりうるトポロジカルな条件が求まったので次につなぎ変わりの物理的性質 に話を進める。その前に，いくつかの言葉の定義を行っておく。これまでは 2 本の磁力線に注目 したが実際には磁場に空間的拡がりがあり，線と線ではなく面と面のつなぎ変わりである。つな ぎ変わりが生じる場所は点（ $\mathrm{x}$ 点）ではなく一般には線分となる。［図 2 ] に示すようにつなぎ 変えの生ずる線分 (各x点を結んだ線)をリコネクション線と呼ぶ。上に述べたトポロジカルな

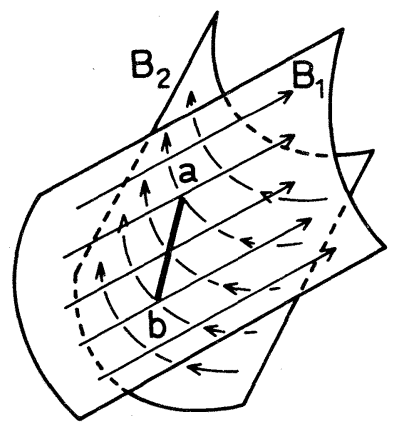

图2. 3次元的なリコネクションの トポロジー。リコネクション はリコネクション線上 $(a-b)$ で起きる。

議論からわかる通り，つなぎ変えの主役は反平行成分であり，共 通成分 (平行成分) 注それには直接関与しない。このことは共通 成分 (平行成分) があるとすれば，その成分はリコネクション線 に沿っていることを意味する。従って, 上の議論からリコネクシ ョン線は $\mathrm{B}_{1}$ と $\mathrm{B}_{2}$ の接平面上で $\mathrm{B}_{1}$ となす角を $\alpha$ とすると

$$
\tan \alpha=\frac{\mathrm{B}_{1}-\mathrm{B}_{2} \cos \theta}{\mathrm{B}_{2} \sin \theta}
$$

となる（ $\mathrm{B}_{1}$ と $\mathrm{B}_{2}$ が完全に反平行の場合は $\mathrm{B}_{1}$ に垂直）。

また， $\mathrm{B}_{1}$ 及び $\mathrm{B}_{2}$ を含む磁気面が互いに接近するとその接平 面内に電流が流れる。しかも，この電流もまたリコネクション線 に沿って最も強く流れることになる。逆に言えば,この電流の存 在によって反平行成分が保たれている。磁気りコネクションが磁 場の拡散, 即ち, 電流の散逸を必要とすることを考えるとき, リコネクション線に沿って電流が 強くなるという事実は（1）の条件を満たす 2 つの磁気面を接近させてやれば接触線（リコネクシ ヨン線）で電流が増大し，少しでも電気抵抗があれば磁力線のつなぎ変えがリコネクション線上 で進行することを示唆している。このようにりコネクション線は磁場のトポロジーを変える上で 最も特異でしかも重要な㗢きをする場所である。

さて，ここで本題の磁気リコネクションの物理的性質に戻ることにする。今，話を簡単にする ためにリコネクション線に垂直な面に着目する。ここではこの面をリコネクション面と呼ぶこと 


\section{佐 藤}

にする。リコネクション線 ( $\mathrm{x}$ 点)に流れる電流によってリコネクション面内の反平行磁場成分 は散逸し,リコネクション線に向って吸い込まれていく。これに伴いプラズマも吸い込まれてい く。その結果, 磁場は消㓕していくが, プラズマはリコネクション線に沿って蓄積し, プラズマ 圧が上昇する。磁場の散逸によるオーム加熱はプラズマ圧の上昇を加速する。当然の成行きとし てプラズマはリコネクション領域から脱出を計る。一般にはリコネクション線近傍を除いて電流 も少なく磁場の散逸が無視できると考えられるからそこでは凍結が再び成り立つものと考えてよ い。従って,リコネクション線から脱出するプラズマはそこにあった磁束を伴っていく。この様 子を画いたのが[図 3$]$ である。

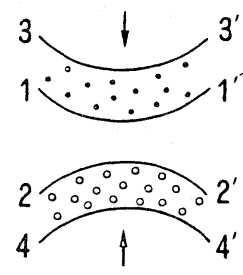

(a)

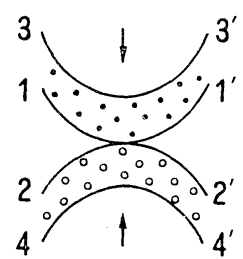

(b)
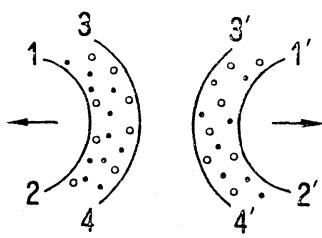

(c)

図 3.リコネクションプロセスを示す概念図

このように，2つの領域の磁力線がスクウェアダンスのパートナーチェンジのように互いに 異った相手と手をつなぎ変えると同時にりコネクション線を通して磁束の輸送を行う。この機構 を我々は「磁気りコネクション」と呼ぶ。従って,リコネクション線を通して単位時間にある領 域から他の領域に輸送される磁束の大きさをもって磁気リコネクションの強さと定義することが できる。

リコネクション線に吸い込まれるプラズマの速さを $\mathrm{v}_{1}$ （他方の吸い込み速度を $\mathrm{v}_{2}$ とする） とすると単位時間に吸い込まれる磁束 $\Phi$ は次式で与えられる。

$$
\Phi=B_{1} v_{1} d=B_{2} v_{2} d
$$

ここにdはリコネクション線の長さ。これはリコネクション線に沿うポテンシャル差と解釈する こともできる。従って

$$
\Phi=E \mathrm{~d}=\eta \mathrm{jd}
$$


磁気りコネクションの物理

と表わすこともできる。ここに E は電場，クはリコネクション線上の電気抵抗で， $\mathrm{j}$ は電流であ る。（4）及び（5）式で， $\mathrm{v}$ 及び $\mathrm{j}$ は未知の量であり，これらを自己無撞着に求めることが磁気り コネクション理論の一つの目標である。

次に，磁気リコネクション機構のもたらす物理的役制について議論する。［図３］において黒 丸及び白丸はプラズマ粒子を表わしたもので，この図からわかるように，リコネクションが生じ ないとすればお互いに混ざり合うことのなかったプラズマ同志がリコネクションを通して混ざり 合う結果となる。同時に，それまで運命を共にしていた者同志は永久に離別することにもなる。 磁気りコネクションのもたらす最も大きな物理的役割はこの“離合集散”作用である。トカマク において有理面上のどこかでリコネクションが生じ有理面が破壊されたとすると，この離合集散 効果によって有理面内部のプラズマはつなぎ変わった磁力線に沿って自由に有理面の外に出るこ とができるようになる。リコネクションが十分発達し，壁の近くの磁力線とプラズマ中心部の磁 力線がつながるまでになると閉じた磁気面で閉じ込められていたプラズマ粒子は全て壁に逃げて しまうことになる。これがディスラプションである。同様に，太陽風と磁気圈を隔てる磁気面に おいてリコネクションが生じると，太陽風粒子は磁気圈内に自由に侵入することができるように なる。

このように磁気りコネクションは磁気面を横切る大規模なプラズマの循環・輸送をもたらす作 用をもっている。この作用のうち “離散”作用はプラズマの閉じ込めという立場からはきわめて 危険なものであるが，一方，“集合”作用の方に目を向けると逆に，異った起源のプラズマを結 合させるという効果をもっている。このことは閉じ込め磁場配位の整形を可能にするのみならず， 電源から磁場を切り離し，自由空間に閉じた磁気面を作りうる可能性をも示唆している。この作 用を積極的に利用する閉じ込め方式として新しく生まれた概念が，いわゆる“コンパクト・トー ラス”である。逆磁場ピンチ（R F P ）の自己反転機構も磁気りコネクションの離合集散作用の 結果と解釈することができる。

この離合集散作用の他にもう一つ重要な役割を磁気りコネクション機構は有している。既に述 ベたように，磁気りコネクション過程の物理的性質はリコネクション線を通して磁束の輸送を行 らことである。その際一部はオーム加熱としてプラズマ加熱に費やされる。しかし，大半は拡散 領域から下流に向ってはき出される（リコネクション線に向って吸い込まれる領域が上流）。次 節で述べるPetschek モデルによると，はき出される速度はアルフベン速度になる。また，§5 でのべる外部駆動りコネクションの数值シミュレーションによると磁気音速を越える超高速ジェ 
ット流が生成される。このことは磁気りコネクション機構が磁気エネルギーから運動エネルギー への高効率変換機構に疗りうることを示唆している。この巨視的なプラズマ加速のみならず，磁 気リコネクション機構は微視的な粒子加速機構としても重要な働きをする。リコネクションに伴っ てリコネクション線に沿って静電ポテンシャルが発生することは先に述べた通りである（（4） 式 )。従って, 電子及びィオンはポテンシャルエネルギーまで加速される。のみならず, 外部駆 動リコネクションに伴って, スローショックが発達することが知られている。粒子, 特にラーマ 一半径の大きいイオンはこのスローショック面で急激な非断熱的加速を受けることが予想される (後述)。このように, 磁気りコネクション機構は, プラズマの大規模な輸送としてのみならず, 巨視的並びに微視的プラズマ加速機構としても重要な㗢きをする。

§4. 理論モデル

磁気リコネクション過程を記述する理論的モデルはいくつか出されているが, 基本的には $2 つ$ のタイプに分けることができる。一つはPetschek モデルと呼ばれる開いた系における磁気り コネクションモデルであり，もう一つはテアリングモードと呼ばれる内部モードの不安定性に起 因する磁気りコネクションである。前者は太陽フレアや磁気圈サブストームなど宇宙空間プラズ マ現象を説明する目的で研究が進められてきたもので, 磁気りコネクションのエネルギー解放機 構としての役割に重点が置かれている。一方,テアリングモードは核融合プラズマにおける崩壊 現象を中心に研究が進められ, 磁気りコネクションの大規模輸送機構として重要な働きをする。

歴史的に見ると磁気りコネクション機構は, 宇宙プラズマにおける爆発的なエネルギー解放を 説明する機構として考え出されたもので，その原型はGiovanelli（1946）の太陽フレアを磁 気中性 $\mathrm{x}$ 点における放電現象としてとらえたのに端を発すると考えられる。その後, D ungey (1953) がx点のダイナミックスを考察し, 現在の意味での磁気りコネクション理論が開始さ れた。1950年代後半から 60 年代にかけ, リコネクションを磁場の拡散のみからとらえる拡散 モデル, いわゆる Sweet -Parker モデルが展開された。このモデルでは, リコネクション 速度が拡散速度に強く支配されているために非常に遅く, フレア現象のような爆発的現象の説明 はむずかしい。この理由から一時リコネクション研究が下火となったが, リコネクション過程に アルフベン波の役割を導入する新しいより現実的モデルがPetschek（1964)により提唱さ れるに及んで再び第 2 のリコネクション時代が到来した。

一方, シート・ピシチの抵抗性不安定性の研究の結果として, Furth - Killeen -Rosen - 
bluth（1963）はシート電流をフィラメント状に切り裂くテァリングモード不安定の存在を発 表した。この不安定性は, その後トカマクにおける有理面の破壊という現象に結びつき, 現在で はトカマクのディスラプションの原因と考光られるに至っている。

この節では, 磁気りコネクションの代表的理論モデルであるPetschek モデルとアテリング モード不安定について簡単に触れる。

§4. 1 Petschek モデル

リコネクション線が無限に長いと考え, それに垂直なりコネクション面内に話を限ることにす る。即ち，2次元リコネクションを考える。話を更に簡単にするためつなぎ変わる磁場の強さは 相等しい, $\left|\mathrm{B}_{1}\right|=\left|\mathrm{B}_{2}\right|$, とする。今, ある点 $\mathrm{x}$ で局所的に磁場のつなぎ変りが発生した
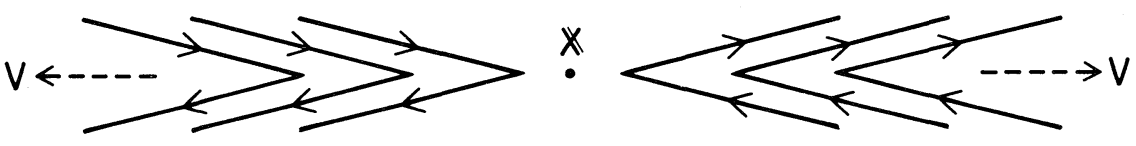

図 4 .つなぎ変わった後の磁力線トポロジー。折れ曲がりが生じるため張力で外側にはじき出される。

とする。つなぎ変った磁力線は［図4］に示すように折れ曲がって流出する。この磁力線の曲が り浽張力によって元に戻ろうとする。Petschek はこの磁力線の張力による復元力が働きリコネ クション過程の磁力線トポロジーは[ 図5 ]のようにな ると考光た。従ってつなぎ変った磁力線の間隔は上流の それに比べ長くなり, 磁気エネルギーが減少する。即ち, プラズマの運動エネルギーに変換されると考えた。

Petschek モデルのもう一つの優れた点は[図 5$]$ に 示す磁力線の折れ曲がる波面の存在を予想したことであ る。流れの方向に沿っていくと磁場の強さはこの波面を 越えて娍少している。流入速度が磁気音速に比べて小さ いと仮定すると, 定常流に対しては, プラズマ圧は逆に 流れに沿って上昇する。この磁気圧とプラズマ圧の逆位 相関係はこの波面がスローモードであることを示唆して いる。しかも，波面で磁場が折れ曲がっているというこ

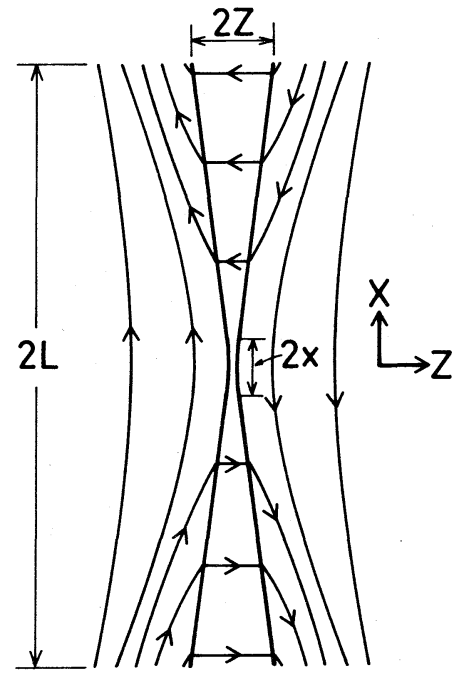

図 5.Petschek モデルの概念図 
とはこの波面がスローモードのショックであることを意味している。要訳するとPetschek モ デルはスローショックを導入することによってエネルギー変換を増大させようというモデルであ ることが結論される。

定常過程を考えると, 連続の式から

$$
\mathrm{v}_{Z} \mathrm{x}=\mathrm{v}_{\mathrm{X}}(\mathrm{x}) \mathrm{Z}(\mathrm{x})
$$

をうる。変数は $[$ 図 6 ]を参照のこと。 $\mathrm{x}$ 方向の力のバランスから近似的に

$$
\frac{\mathrm{d}}{\mathrm{dx}}\left(\rho \mathrm{v}_{\mathrm{x}}^{2} \mathrm{Z}\right) \cong \frac{\mathrm{B}_{Z} \mathrm{~B}_{\mathrm{xo}}}{\mu_{0}}
$$

をうる。

スローショック面への流入速度 $\mathrm{v}_{Z}$ をスロ

ーモードの位相速度ととると

$$
\mathrm{v}_{z}=\frac{\mathrm{B}_{z}}{\sqrt{\mu_{0} \rho}}
$$

(6) - (8)式から

$$
\begin{aligned}
& \mathrm{Z}=\mathrm{M}|\mathrm{x}| \\
& \mathrm{v}_{\mathrm{x}}=\mathrm{V}_{\mathrm{A}}
\end{aligned}
$$

をうる。ここに, $\mathrm{M}=\mathrm{v}_{Z} / \mathrm{V}_{\mathrm{A}}, \mathrm{V}_{\mathrm{A}}=$ $\mathrm{B}_{\mathrm{x} 0} / \sqrt{\mu_{0} \rho} \circ(10)$ 式は流出速度が

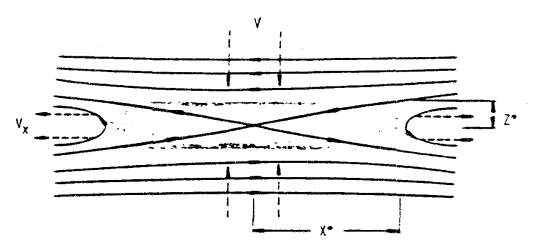

上流側のアルフベン速度になることを示している。

磁気りコネクションの強さを（4）式で定義したことを思い出すと, 流入速度 $\mathrm{v}_{Z}$ を既知のプラ ズマ量で与える必要がある。（8）式からこれは $\mathrm{B}_{Z}$ を求めることと等価である。これを評価する には拡散領域外の外部領域の解を求めることになるが，その計算は省略し，結果だけをあげると，

$$
\mathrm{M}_{\max } \approx \frac{\pi}{8 \ln \left(\mathrm{M}_{\max } \mathrm{L} / \mathrm{z}^{*}\right)}
$$

となる。ここにLはスローショックの存在する $\mathrm{x}$ 方向の長さ， $\mathrm{z}$ * は拡散領域の巾を示す。一般 に $\mathrm{L} / \mathrm{z}^{*} \gg 1$ と考えられるから, $\mathrm{M}_{\mathrm{max}}$ は $z^{*}$, 即ち, 電気抵抗にほとんどよらず,

$$
\mathrm{v}_{\mathrm{Z} \max } \approx 0.1 \mathrm{v}_{\mathrm{A}}
$$


で近似される。従って，これを(4)式に入れると

$$
\Phi_{\text {max }} \approx 0.1 \mathrm{~B} \mathrm{~V} \text { A }
$$

となる。要訳すると, Petschek モデルはスローショックが生成されれば電磁流体的時間スケー ルでエネルギー変換が起こることを示唆し応と言える。

$\S 4.2$ テアリングモード

テアリングモード不安定性に対する解析は既に馴染み深いのでここではそのエッセンスだけを 紹介する。まずエネルギー原理を用いて説明する。

断熱部と非断熱部とに分けて考える。Petschek モデルのように開いた系では外部からのポイ ンティングフラックスが存在しうるが，ここでは外部からのフラックスの流入はないものと考光 る。磁気エネルギーの変動成分に対する式は

$$
\frac{\partial}{\partial \mathrm{t}} \int \frac{\mathrm{B}_{1}^{2}}{2 \mu_{0}} \mathrm{dV}=-\int \mathbf{E}_{1} \cdot \mathbf{j}_{1} \mathrm{dV}
$$

となる。ここで電流 $j_{1}$ を断熱部分 $j_{1}$ A と非断熱部 $j_{I N}$ に分け，

$$
\mathbf{j}_{1 \mathrm{~N}}=\sigma_{\mathrm{eff}} \mathbf{E}_{1}
$$

とひとまず置いておき， $j_{1 \mathrm{~A}}$ の寄与を，テアリングモードは雾周波で磁気モードであるという 仮定から求めると

$$
\mathrm{E}_{1}^{*} \cdot \mathrm{j}_{1 \mathrm{~A}}=-\frac{1}{2 \mu_{0} \mathrm{~L}_{\mathrm{S}}^{2}} \operatorname{sech}^{2}\left(\mathrm{z} / \mathrm{L}_{\mathrm{S}}\right)\left|\mathrm{A}_{1 \mathrm{y}}\right|^{2}
$$

をうる。ここにAはベクトルポテンシャルの成分で, 初期平衡解として反平行磁場配位を与える ハリス解を用いた。即ち,

$$
B_{0}(z)=B_{0} \tanh \left(z / L_{S}\right)
$$

（17）式を（15）式に用いると

$$
\begin{aligned}
& \frac{\partial}{\partial \mathrm{t}}\left\{\frac{1}{2 \mu_{0}} \int \mathrm{d} z\left[\left|\frac{\mathrm{dA}_{1 \mathrm{y}}}{\mathrm{d} z}\right|^{2}+\mathrm{k}_{\mathrm{X}}^{2}\left|\mathrm{~A}_{1_{\mathrm{y}}}\right|^{2}-\frac{2}{\mathrm{~L}_{\mathrm{S}}^{2}}\left|\mathrm{~A}_{1_{\mathrm{y}}}\right|^{2} \operatorname{sech}^{2}\left(\frac{\mathrm{z}}{\mathrm{L}_{\mathrm{S}}}\right)\right]\right\} \\
& =-\int \mathrm{d} z \sigma_{\mathrm{eff}}\left|\mathrm{E}_{1 \mathrm{y}}\right|^{2}
\end{aligned}
$$


左辺は磁気エネルギーの変化 $\left(\delta \mathrm{W}_{\mathrm{B}}\right)$ を示し, 右辺はプラズマの熱エネルギーの変化 $\left(\delta \mathrm{W}_{\mathrm{p}}\right)$ を示す。従って，このモードが不安定になるには $\delta W_{\mathrm{B}}<0$ 。(19)式左辺の第 3 項のみが不安定 に寄与寸ることがわかる。この項は磁気変動に伴う $\mathbf{E}_{1} \cdot \mathbf{j}_{1_{\mathrm{A}}}$ からきたものであることから， プラズマの運動エネルギーに変換される。（19)式から，不安定になる必要条件として， $\mathrm{L}_{\mathrm{S}}^{2} \mathrm{k}_{\mathrm{x}}^{2}$ $<1$, 即ち, 長波長モードほど不安定に寄与することが結論される。更に，(19)式は系が不安 定となる条件として, なんらかの電気抵抗の存在を要求している。この抵抗の原因として, 古典 的な抵抗の他に粒子からのチェレンコフ放射や粒子の慣性による見かけ上のドラッグなどがあげ られる。これが無衝突テアリング不安定性と呼ばれるものである。これに対し，古典抵抗による 散逸が原因となる場合を抵抗性テアリング不安定と呼ぶ。

テアリングモードの線形振舞を解析的に調べるには，方程式系が複雑で一般的な解を求めるこ とが難しく, Petschek モデルと同様, 拡散領域と外部領域の境界で, 両者の解の対数飛び $\left(\Delta^{\prime}\right)$ が整合するという条件を課すという方法がとられる。この解析の詳細は割愛して, ここで

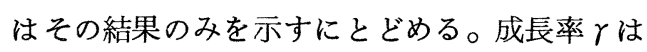

$$
\gamma=\left[\frac{2}{\pi} \frac{\Gamma\left(\frac{5}{4}\right)}{\Gamma\left(\frac{3}{4}\right)} \Delta^{\prime} \mathrm{L}_{\mathrm{S}}\right]^{\frac{4}{5}} \tau_{\mathrm{R}}{ }^{-\frac{3}{5}} \tau_{\mathrm{A}}-\frac{2}{5}
$$

ここに「はガンマ関数, $\Delta^{\prime}=2\left(1-\mathrm{k}_{\mathrm{X}}^{2} \mathrm{~L}_{\mathrm{S}}^{2}\right) / \mathrm{k}_{\mathrm{x}} \mathrm{L}_{\mathrm{S}}, \tau_{\mathrm{R}}$ は拡散時間, $\tau_{\mathrm{A}}$ はアルフベ ン伝播時間。この (20) 式はテアリングモードによるリコネクションの起きる時間スケールがほ ぼ挔散時間とアルフベン伝播時間の幾何平均で決まることを結論している。従って, Petschek 的磁気リコネクションに比べ一般には遅いプロセスであることがわかる。このことが，爆発的エ ネルギー変換機構として, Petschek モデルがテアリングモードに比べょり有効であることの理 由である。

§5. 数值シえュレーション

磁気りコネクションは本質的にダイナミックな振舞を伴うもので, しかも, ショックが関与す るなど強い非線形性を示す現象である。従って, 理論解析的には, 前節のように, 開いた系に対 しては定常モデル, 閉じた系に対しては線形理論が取扱える限度である。その時間発展, エネル ギー変換等を具体的に知るには現在では数值シミュレーションに頼るのが最も賢明な方法であろ う。 
磁気リコネクションの物理

ここでは磁気エネルギーからプラズマの運動エネルギーへの最も有効なリコネクション機構と 考えられる外部駆動磁気リコネクションのMHD シこュレーションとプラズマ粒子の磁気面を越 えての混合作用が効果的に現われるトカマクのテアリングモード不安定のMHDシミュレーショ ン例をいくつかあげる。

\section{$\S 5.1$ 外部駆動りコネクション}

宇宙に㧍けるプラズマは全て磁場を有するプラズマと考光てよい。磁場がどうして生まれるか はさておき, 宇宙, 銀河, 中性子星, 太陽, 木星, 地球, これらが独自の磁場を有している。し かも，アクティブな星からはプラズマ流が吹き出している。これらのプラズマ流は固有の磁場を その星の重力圈外に持ち出す, その結果, 他の星の磁場と衝突する。このような事象は宇宙のあ ちこちで起きていると考光られる。§3で述べたトポロジカルな条件が満たされると, 磁気りコ ネクションが生じ，様々なドラマが展開されると想像される。このように自然界で発生すると考 えられる磁気ツコネクションは，お互いのプラズマがぶつかり合うことによって発生する場合が 多い。このような磁気りコネクションを外部駆動リコネクションと呼ぶ。

・自然界のみならず，このような強性リコネクション注実験室プラズマにおいてダイナミックに 閉じ込め磁場配位を作り出すことにも，また電流駆動（磁束共給）にも利用することができる。 初期条件として反平行磁場配位であるハリス解から出発する。磁気中性面に向って磁場に垂直 な二つの面から磁場をもつプラズマを局所的に流入させる。すると磁気中性面は磁気音波によっ て圧縮され磁気中性面電流（反磁性電流）が増大する。この際低域混成ドリフト波が強く励起さ れ，異常抵抗が増大し，リコネクションか誘発される。（粒子シミュレーションにより異常抵抗 の増大が実証されている）。また，圧縮された中性面から外に向うスローモードが励起され，中 性面に向うプラズマ流との相互作用で位相速度の遅い斜め云播のスローモードはスローショック に発達する。スローショック波面に沿って反磁性電流が集中するために $\mathrm{j} \times \mathrm{B}$ 力が増大する。 同時にショック面で $\nabla$ ” $\mathrm{p}$ を增大寸る。その結果, プラズマはつなぎ変った磁場を伴って下流 に急激な加速を受ける。これがシミュレーション結果の要訳であり，発達したリコネクションに 伴う磁力線構造 (実線) とプラズマ流 (矢印) の加速の様子を示したのが[ 図7 ]である。

シミュレーションは種々の外部からの流入速度, 電気抵抗モデルに対し行われたが, [図 8 ] に示すようにリコネクションの発達はほとんど抵抗モデルには依存せず（上図）, 流入速度に 大きく依存していることが結論される（下図）。（縦軸はリコネクション線に沿って誘起された 

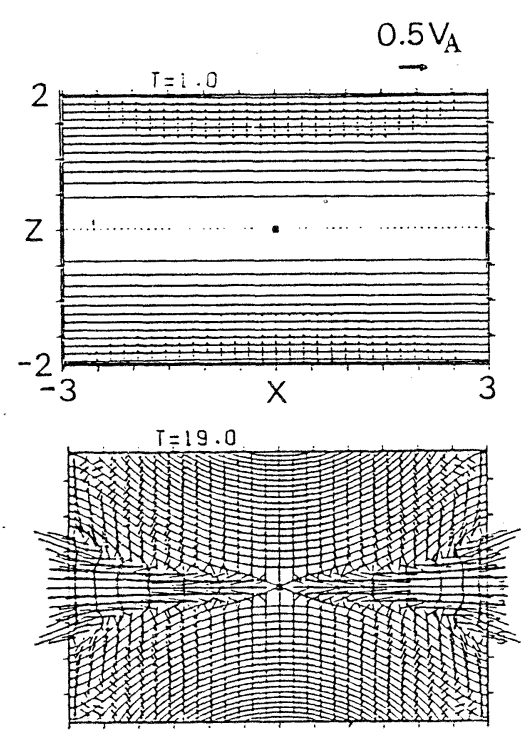

図 7. 外部駆動リコネクションによって発達 した磁力線とプラズマ流の構造。

(Sato and Hayashi, Phys. Fluids, 22, 1189,1979 )

電場を与えている。（5）式からリコネクショ の強さは誘発された電場に比例していること に注意。

このシミュレーションからプラズマが超アルフベン流まで加速されることが明らかとなったが， リコネクションによって作られた複雑な電磁場中での個々の粒子の加速という課題も太陽フレア や磁気圈サブストームなど自然界の爆発現象に関連した興味あるものである。MHDシミュレー ションで得られた時間発展する電磁場中でのテスト陽子の軌跡及びエネルギーの時間発展を追つ た一例を[図 9 ] に示す。スローショックにぶつかった陽子が急速に高エネルギーに加速されて いるのがわかるであろう。

現在では 3 次元 MH D シュュレーションも行われ, 沿磁力電流の発生など宇宙プラズマへの応 用として興味ある新しい現象も見つかっている。 


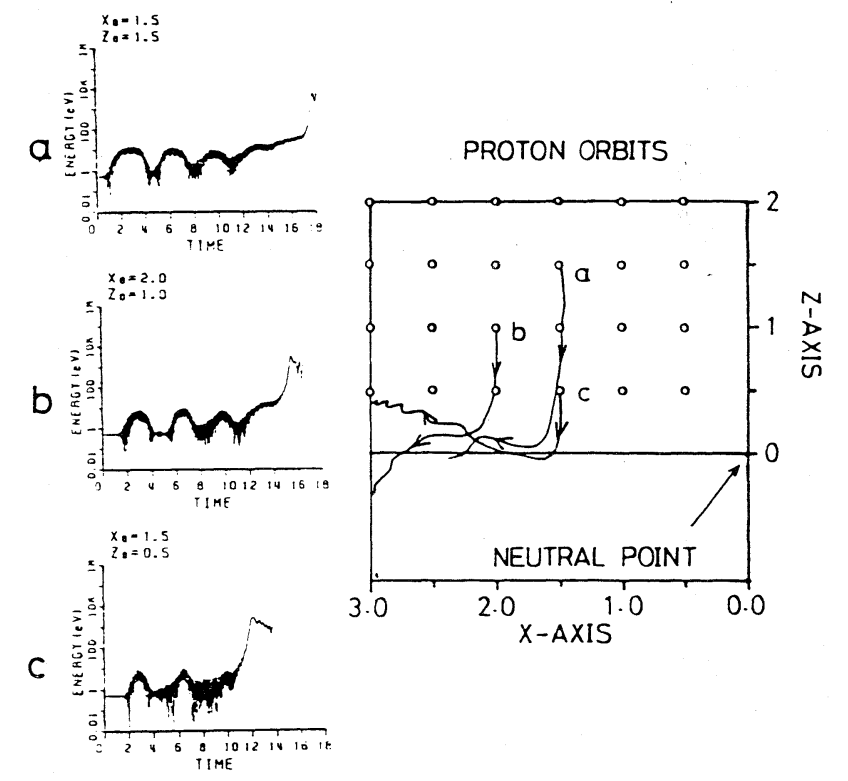

図 9.スローショックによって陽子が急激に加速されることを示すテスト 粒子解析 (Sato, Matsumoto, Nagai, J. Geophys. Res., 87, 6089, 1982)。

\section{$\S 5.2$ 抵抗性テアリング不安定}

トカマク配位のようにヘリカル磁場にシアーがある場合, ある一定の回転変換をもつ磁場成分 を差し引くと, その回転変換に対応するモード有理面を境いにしてポロイダル磁場成分が逆転す る。ミ3で論じた磁気りコネクションの起きる条件に立戻ると，モード有理面が存在するという ことと (1) 式が満足されるということとは等価であることがわかる。従って, モード有理面が磁 気中性面となり，リコネクションの発生が可能となる。

モード有理面は一つとは限らず，一般にはいくつかのモード数に対応する有理面が存在する。 トカマク配位では低いモードが内側に高いモード有理面が外側にできる。従って, 外側のモード ほどプラズマと壁との混合作用が可能となり，閉じ込めにとっては危険なモードとある。しかし ながら，(20)式からわかる通り，成長率は $\left(\Delta^{\prime}\right) 4 / 5 \approx\left(\mathrm{k}_{\mathrm{x}} \mathrm{L}_{\mathrm{S}}\right)^{-4} / 5$ に比例する ために低モードほど成長しやすい。即ち，中心部から不安定性が成長すると考えられる。この低 モード ( $\mathrm{m}=1$ ) のテアリング不安定が内部ディスラプションの原因だとされている。これに対 


\section{佐 藤}

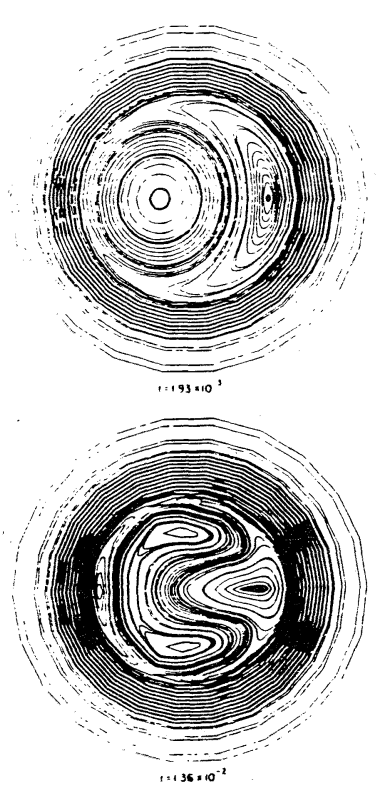

図10. $m=1$ テアリングモードの発達 により中心部の磁場構造の破壊 を示す解析例 (Waddell，

Rosenbluth, Monticello,

White, Nuclear Fusion, I6,

528, 1976)
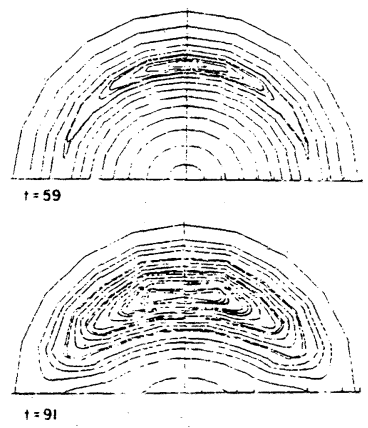

図11. $m=2$ テアリングモードの発達 によるデイスランションを示す 図 (White, Monticello, Rosenbluth, Phys. Rev. Lett., $39,1618,1977$ )

し, $\mathrm{m}=2$ モードの成長が主ディスラプションに直 接関係していると考えられている。

[図 10$]$ は 101 テアリングモードによってプラ ズマの中心部の磁場構造がつぶされるシミェレーショ ン結果の一例である。これに対し， $\mathrm{m}=2$ モード成長 のシミュレーション結果は［図11]のようになる。

[図 9 ]に比べ, 磁場構造の破壊される領域がより外側にまで拡がっている様子がわかる。これ らのシミュレーションは単一モード解析であるが, 多重へリシティモード解析を行った結果を

[図 12 ] に加えでおく。b図はある断面を貫く磁力線の軌跡を示したもので, 多モードの成長 により磁気面が破壊され，プラズマ粒子の混合が起きたことが効果的に示されている。

§6. おわりに

宇宙のプラズマはほとんど磁場を伴っている。しかも, 重力, 回転, 放射圧, 加熱などの作用 によってプラズマは動きまわっている。それに伴って, 異った起源のプラズマが衝突したり，ね じれたりする機会注頻繁に起こる。従って, 宇宙で磁気りコネクションが発生する確率は非常に 高い。そのスケールによって、プラズマに解放されるエネルギーは時には膨大な量になりうる。 その解放されたエネルギーの大半はプラズマの巨視的（バルク）な加速に費やされるが，その一 

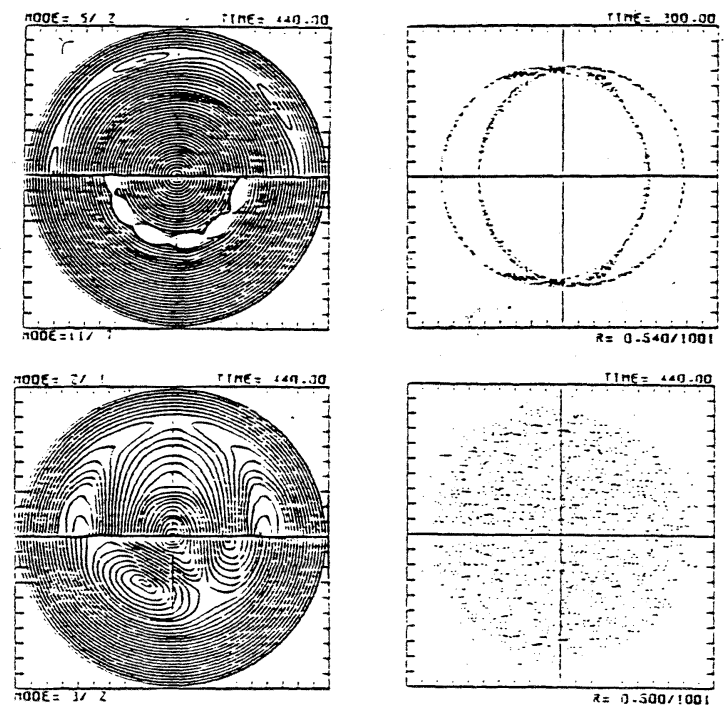

図12、複数個のモードを考慮したテアリングモード発達の解析 結果。左図は磁場構造, 右図は磁力線の軌跡を示す。

(Takeda, Kurita, Azumi, Toda, Takizuka, Tsunematsu, Tokuda, Itoh, US-Japan Workshop Proc. on 3 D MHD Studies, Oak Ridge, p. I 16, 1981)

部は直接高エネルギ一粒子の生成にもつかわれる。また，一旦バルク加速に使われたエネルギー もダブルレイヤーなどを発生させ，それによって粒子が高速に加速されることも考えられる。加 速された高速粒子からは電磁波となって遠方に放出される。地球といら宇宙の一点にまで到達す る電磁波もある。このように考えると，宇宙プラズマで発生する現象の中で我々が触れることの できる現象の中にはこの磁気りコネクションに直接関係したものがかなりの部分を占めているよ うな気がする。

地上の実験室においても，これまではむしろ核融合プラズマにとっては厄介者でしかなかった 磁気リコネクションも，物は使いようで，その性質，役割を十分理解することによって有効に核 融合プラズマに応用できる方法が考光出されるはずである。逆磁場ピンチ（RF P ），スフェ口 マック，逆磁場テータピンチ（ＦＲＣ）などは正にその典型であり，トカマクやミラー装置にも 恐らく有効な利用法があるはずである。 


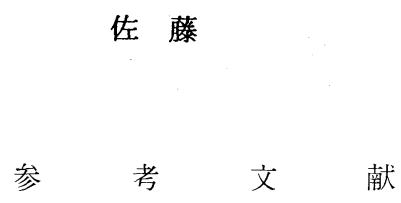

文中に特に文献番号をつけるということはしなかったが，この解説に特に関係のある文献を 以下にいくつかあげておく。

1) H. E. Petschek, Magnetic field annihilation, NASA Spec. Publ. SP-50, pp. 425-439, 1964 .

2) V. M. Vasyliunas, Theoretical model of magnetic field line merging, Rev. Geophys. Space Phys., 13, pp. 303-336, 1975.

3) H. P. Furth, J. Killeen, M. Rosenbluth, Finite-resistive instabilities of a sheet pinch, Phys. Fluids, 6, pp. 459-484, 1963.

4) T. Sato, T. Hayashi, Externally driven magnetic reconnection and a powerful magnetic energy converter, Phys. Fluids, 22, pp. 1189-1202, 1979. 